\section{Honesty's the best policy}

\section{J. L. Heilbron}

Science à la Mode: Physical Fashions and Fictions. By Tony Rothman. Princeton University Press: 1989. Pp. 207. \$19.95, $£ 12.50$.

IN THE middle of the eighteenth century, the Berlin Academy of Sciences advertised an essay competition on the question, "Is it useful for men to be deceived?". In so far as they have a common theme, the six essays served up here under the opaque title Science à la Mode may be regarded as answers to this enduring question.

The essays, four of which have been published previously, consider modern cosmology (twice), geodesics, entropy, nuclear winter and the career of Evariste Galois. The first four are mostly high-level vulgarization. The last two criticize scientists who play to the public, bend to politics or write poor history. Even when popularizing, however, Rothman stops to admonish his colleagues (he is a cosmologist) for coveting their own hypotheses and evolutionary biologists for misusing ideas (the doctrine of entropy) they do not understand. Many examples of both sorts of self-deception come to mind. The tychonic system, the theory of phlogiston, the electromagnetic ether and light conceived as waves or particles, or both, or neither, have had their over-fond exponents; and physicists themselves have helped to cheapen their ideas by advertising parallels between quantum theory, depth psychology and Eastern mysticism.

It is not self-deception, however, but wilful misrepresentation of technical concepts or conscious relaxation of professional standards against which Rothman aims his two most useful essays. One records attempts to evaluate the claims made by Carl Sagan's group about the likelihood that man will exterminate himself and herself by throwing up enough smoke in a nuclear war to shut out the light of the Sun. Rothman faults the trumpeters of this dusty eschatology on two counts: their shaky numbers and hypotheses do not authorize the conclusion that we can do for ourselves what Alvarez's meteor may have done for the dinosaurs; and, by shifting attention from the colossal number of direct and immediate casualties from any serious nuclear exchange, they encourage pursuit of technical palliatives to the twilight rather than urgent efforts to remove the arsenals that might cause it. Rothman has no patience with colleagues who doubted the reliability of the wintry calculations but refused to say so, thinking that the prospect of the end of the human race might promote the cause of dis- armament. Here the problem of the utility of deception re-presents itself. Rothman's solution is that honesty is the best policy.

The essay on Galois corrects the story commonly told by scientists of a young unappreciated genius, persecuted for his political opinions and killed in a duel arranged by police agents. Galois was a trouble maker, his genius was recognized, and he died for love not revolution. (The historian could supply hundreds of similar cases in which scientists have neither tried nor wanted to get the story straight; a short list appears in Franz Stulhofer's recent book, Lohn und Strafe in der Wissenschaft: Naturforscher im Urteil der Geschichte, published by Böhlau, Vienna,

\section{Cellular update}

\section{Ron Laskey}

Molecular Biology of the Cell, 2nd Edn. By Bruce Alberts, Dennis Bray, Julian Lewis, Martin Raff, Keith Roberts and James D. Watson. Garland:1989. Pp. 1218 + index. Hbk \$51.95; pbk £24.95. The Problems Book. By John Wilson and Tim Hunt. Garland:1989. Pp.354 + index. Pbk \$14.95, £8.

THE first edition of Molecular Biology of the Cell appeared in 1983 and marked a milestone in the publication of textbooks in the life sciences. In order to cover the full range of cell biology, a team of authors was involved, but the material was integrated in such a way that it read as the work of a single hand. The book's success was immediate, and its appeal - to novice students, university teachers and specialized researchers - remarkably broad.

But six years is a long time, especially in such a fast-moving field as cell biology. So for some time there has been an impatient clamour for a second edition, and there is no doubt that an up-dated version was worth writing. The only question left for a reviewer is "Does it match the standard of its predecessor?". In my opinion the answer is "No". It doesn't match the first edition. It surpasses it.

A first glance at the "Contents in Brief" could mislead the reader into thinking that the second edition is almost the same as the first. There is only one entirely new chapter (an excellent one on cancer) and the old chapter on the cell nucleus has been split in two to generate a separate discussion of control of gene expression. Apart from these changes and some reordering of the contents, the book at first sight looks much the same as before.

It is only on starting to read that one realizes how radical the revision has been. Overhaul has not simply involved the addition of new examples, but thorough restructuring of the conceptual framework. in 1987.) Rothman condemns the misrepresenters of Galois for suspending their usual standards of research and for deceiving their students in order to parade a picture of brilliance destroyed by functionaries dumb to the calls of genius. Thence it is an easy step to the caricature that everyone is wrong and stupid but the creative scientist. The caricature may have its tactical uses, but it is bad strategy. Rothman rightly condemns it. "This is a presumption of the highest arrogance [he writes]. Scientists should not be so enamored of themselves."

J. L. Heilbron is in the Office for History of Science and Technology, University of California, Berkeley, California 94720, USA.

In all those cases I can judge, the improvement is substantial. The illustrations are another area of improvement, the explanatory diagrams and dramatic micrographs working in harmony with the text. Here is a commendably up-to-date and accurate account of the best of cell biology.

The advent of the accompanying problems book by John Wilson and Tim Hunt is a further bonus, especially for students. The book follows the main text and allows readers to test their comprehension of facts and concepts through several levels of question. The questions range from filling in the blank in a sentence or identifying a statement as true or false, to solving complex problems, which are often based on real experiments from the literature.

One matter continues to puzzle me. How have the authors managed to pack in so much new information (the developments in cell-cycle control and many other topics besides)? The length of the book is much the same as before, and there has been no sacrifice of the lucid, accessible style that marked the first edition.

So is the book really perfect? No, of course not. It is possible to identify a few niggles, such as a wrong page number in the index and oversimplified 'true or false' questions in The Problems Book. There are also minor points on which I disagree with the authors' emphasis or interpretation. But the overall standard of the new edition is so overwhelmingly excellent that $I$ have no reservations in pronouncing it the best book of its kind - another milestone in biological education.

Ron Laskey is in the Cancer Research Campaign Molecular Embryology Group, Department of Zoology, University of Cambridge, Downing Street, Cambridge CB2 3EJ, UK.

- An English translation of Anatole Abragam's autobiography, Time Reversal, is being published by Oxford University Press, priced at $£ 25$, with a release date at the end of August. The original French version of the book was reviewed in Nature last year. (See Nature 333, $126 ; 1988)$. 